\title{
Wisata Germanggis dan Potensinya Sebagai Prasarana Aktivitas Jasmani Siswa Sekolah Dasar
}

\author{
Indra Jati Kusuma ${ }^{1}$, Kusnandar ${ }^{2}$, Panuwun Joko Nurcahyo ${ }^{3}$, Rifqi Festiawan ${ }^{4}$ \\ ${ }^{1}$ Jurusan pendidikan Jasmani, Fakultas Ilmu-Ilmu Kesehatan, Universitas Jenderal Soedirman, \\ Indonesia \\ E-mail:indrajaks2122@gmail.com¹, rifqi.festiawan@unsoed.ac.id ${ }^{3}$
}

\author{
Menerima: 07 October 2020; Revisi: 26 March 2021; Diterima: 27 April 2021 \\ is https://doi.org/10.24036/xxxxxxxx
}

\begin{abstract}
This study aims to know the potential of Germanggis to be used as infrastructure for physical activities, knowing the inhibiting factors in the development of Germanggis as a physical activity infrastructure, and knowing the supporting factors for Germanggis, to be used as infrastructure for physical activities. This research is a qualitative descriptive study. Data collection techniques were obtained through observation, focus group discussions, interviews, and documentation. Informants are determined by purposive sampling technique for managers and snowball sampling for teachers and students. Data triangulation was used for validity, and interactive analysis by Miles and Huberman's model to analyze the data. The results: The potential of Germanggis, namely having sufficient springs, standing on an area of 1.5 hectares, and there are still 3.5 hectares more to be developed, the air is still cool, the view at sunrise and sunset is good, Inhibiting factors; the road is uphill, the bus route has not been passed, Supporting factors: affordable entrance ticket prices, the availability of worship facilities and food stalls, there are many interesting photo spots, there are camping areas, and the outbound area is still under the arrangement. Conclusion: Germanggis Tourism Object has started to be used by Physical Education Teachers for learning outdoor activity-based physical activities because there are supporting facilities, namely camping ground, outbound, worship facilities and food stalls, photo spots. Germanggis can be used as an outdoor activity-based physical activity learning infrastructure because the teacher and students respond very well after learning outdoor activity-based physical activities.
\end{abstract}

Keywords: Potential of Germanggis, Infrastructure, Physical Activity

\begin{abstract}
Abstrak
Penelitian ini bertujuan untuk mengetahui potensi Germanggis untuk dijadikan prasarana aktivitas jasmani, mengetahui faktor penghambat dalam pengembangan Germanggis sebagai prasarana aktivitas jasmani, dan mengetahui faktor pendukung Germanggis, untuk dijadikan prasarana aktivitas jasmani. Penelitian ini merupakan penelitian deskriptif kualitatif. Teknik pengumpulan data diperoleh melalui observasi, focus group discusion, wawancara dan dokumentasi. Informan ditentukan dengan teknik purposive sampling untuk pengelola dan snowball sampling untuk guru dan siswa.Digunakan trianggulasi data untuk uji keabsahannya, dan analisa interaktif model Miles dan Huberman untuk menganalisa datanya. Hasilnya: Potensi dari Germanggis yaitu memiliki sumber mata air yang cukup, berdiri diatas lahan seluas 1,5 hektar, dan masih ada 3,5 Hektar lagi untuk dikembangkan, udaranya masih sejuk, pandangan saat sunrise dan sunset bagus, Faktor Penghambatnya; jalannya menanjak, belum dilalui jalur bus, Faktor Pendukungnya: harga tiket masuk terjangkau, tersedianya fasilitas ibadah dan warung makan, banyak terdapat spot foto menarik, terdapat area camping, dan area outbond masih dalam penataan. Kesimpulan: Objek Wisata Germanggis sudah mulai digunakan oleh Guru Penjasorkes untuk pembelajaran aktivitas jasmani berbasis outdoor activity karena terdapat fasilitas yang mendukung yaitu camping ground, outbound, fasilitas ibadah dan warung makan, spot foto. Germanggis dapat digunakan sebagai prasarana pembelajaran aktivitas jasmani berbasis outdoor activity karena respon guru dan siswa sangat baik setelah melakukan pembelajaran aktivitas jasmani berbasis outdoor activity.
\end{abstract}

Kata Kunci: Potensi Germanggis, Prasarana, Aktivitas Jasmani 


\section{PENDAHULUAN}

Pariwisata

olahraga merupakan perpaduan antara olahraga dan wisata, yang sekarang sudah berkembang dan terus mengalami peningkatan wisatawan (Widodo, 2016). Perjalanan wisata yang berkaitan dengan kegiatan olahraga telah terjadi sejak ribuan tahun yang lalu (Karisma, 2012). Salah satu tulisan tertua yang menuliskan hubungan antara olahraga dan pariwisata muncul pada sebuah jurnal yang berjudul, Sport and Tourism yang ditulis oleh Don Anthony untuk Central Council of Physical Recreation di Inggris tahun 1966, yang meninjau kemungkinan keterlibatan olahraga dalam memainkan peran di dunia kepariwisataan (James \& Williams, 2017).

Data Statistik di Canada tahun 2008, pariwisata olahraga merupakan segmen yang berkembang paling cepat pada industri pariwisata dengan pengeluaran tahunan mencapai $\$ 3,4$ miliyar (Komaini, 2018). Dewasa ini pariwisata olahraga sudah menjadi sebuah unsur yang penting dalam dunia pariwisata karena telah menjadi bisnis pariwisata yang sangat kompetitif (Putra Thama \& Dharmawan, 2019). Seperti ketertarikan dan partisipasinya dalam perkembangan olahraga di industri pariwisata, keinginan orang untuk melakukan perjalanan, untuk bersaing, atau untuk melihat pertandingan olahraga telah menjamur (Castyana, 2013; Feldman \& Matjasko, 2005).

Dalam pembelajaran pendidikan jasmani olahraga, dan kesehatan (PJOK), terdapat materi outdoor activity yang aktivitas jasmaninya dilakukan diluar kelas (Rahayu \& Firmansyah, 2019). Hal ini belum semua diberikan oleh guru pendidikan jasmani di kecamatan Cilongok dengan memanfaatkan lokasi camping ground Germanggis.

Dalam PJOK, seorang anak akan belajar tentang gerak dan belajar melalui gerak. Melalui belajar gerak, anak akan memiliki pemahaman tentang gerakan jasmani dan melalui gerak tersebut anak akan paham tentang kehidupan nyata, sehingga akan bersikap dan berperilaku hidup aktif dan sehat dalam hidupnya (Festiawan, 2020). Setiap gerakan tubuh yang mengeluarkan energi dimaknai sebagai aktivitas jasmani (Festiawan et al., 2020).

Aktivitas jasmani merupakan salah satu sasaran yang hendak dicapai di dalam pendidikan jasmani, olahraga, dan kesehatan (Kamaludin et al., 2020); siswa menjadi terbiasa melakukan aktivitas merupakan salah satu indikator dari kesehatan. Penyajian materi pembelajaran pendidikan jasmani, ditujukkan dalam rangka, membantu siswa supaya mampu memahami fungsi gerak manusia secara efektif dan efisien (Nurcahyo et al., 2020).

Pendidikan jasmani memiliki peran penting dalam mendukung terselenggaranya pendidikan sebagai salah satu proses pembinaan manusia seumur hidup. Dalam pembelajaran di dalamnya terdapat beragam pengalaman belajar, melalui aktivitas jasmani yang dilakukan secara sistematis dan terstruktur, siswa diberikan kesempatan untuk terlibat langsung.

Penyampaian guru secara efektif, menjadi salah satu cara untuk mencapai tujuan pendidikan yang ada pada kurikulum (Festiawan et al., 2019). Hal ini ditekankan agar siswa merasa senang dan antusias selama berlangsungnya kegiatan pembelajaran pendidikan Jasmani (Kusuma et al., 2020). Ruang lingkup pendidikan jasmani salah satunya adanya kegiatan luar kelas (outdoor activities), yang bisa membuat siswa mengenal lingkungan luar dan merasakan langsung apa yang mereka pelajari (Festiawan \& Arovah, 2020).

Pendidikan luar kelas pada dasarnya merupakan pendidikan lintas bidang studi, karena di dalam kegiatannya meliputi seni, ilmu alam, pendidikan jasmani dan home economic (James \& Williams, 2017; Richards et al., 2018; Wicaksono et al., 2020). Pendidikan luar kelas merupakan salah satu dimensi dalam pendidikan jasmani, di mana melalui program kegiatan ini diharapkan konsep diri siswa dapat dibentuk.

Manfaat pendidikan luar kelas dalam membentuk kepribadian siswa dalam; belajar hidup demokratis, belajar lebih banyak mengenai lingkungan fisik dan pentingnya kekayaan alam, memperkaya dan meningkatkan kualitas hidup, memiliki rasa tanggung jawab, memiliki jiwa kepemimpinan, mampu bekerja sama, dan jujur, pentingnya menjaga kesehatan dan kebugaran, kecintaan untuk bertualang,akan tersalurkan melalui kegiatan luar kelas sehingga dapat mengkaitkannya dengan materi pelajaran di kelas

Hal ini sejalan dengan penelitian (Nguyen, 2015) bahwa dalam pendidikan jasmani, banyak guru telah stagnan terlalu lama, dengan berpegang pada olahraga tim favorit mereka dan tinggal di zona kenyamanan mereka sendiri. Beberapa kajian terkait dengan pendidikan jasmani, mengungkapkan perlunya merestrukturisasi kurikulum pendidikan jasmani, dengan variasi mengajarkan siswa kegiatan outdoor yang sehat (Kusuma et al., 2020). 
Salah satu objek wisata yang menyediakan prasarana aktivitas luar kelas tersebut adalah Germanggis. Germanggis lokasinya berada di Desa Karangnangka, Kecamatan Cilongok. Pada tempat ini suasana wisatanya masih asri, ditambah keindahan alam yang bisa menjadi spot untuk berfoto pagi para pengunjung dan menikmati pemandangan Kota Purwokerto yang terlihat dari Bukit Germanggis.

Objek Wisata Germanggis memiliki fasilitas diantaranya adalah tempat untuk berkemah atau camping ground, yang sering di gunakan oleh komunitas maupun pelajar untuk menikmati suasana yang sejuk dan asri. Kemudian ada tempat untuk kegiatan outbound yang masih alami dan memiliki rute yang panjang dan menarik untuk di coba bagi pelajar untuk kegiatan aktivitas jasmani diluar kelas.

Berdasarkan hasil observasi peneliti, bahwa adanya potensi objek wisata germanggis untuk di jadikan aktivitas luar kelas, dibuktikan dengan adanya beberapa sekolah di Purwokerto yang sudah melaksanakan kegiatan luar kelas di Germanggis Camp Area. Selain itu objek wisata Germanggis juga sudah memiliki kerja sama dengan beberapa sekolah di Purwokerto. Untuk mendukung tercapainya tujuan pembelajaran PJOK telah tersedia fasilitasnya di Germanggis.

Pada sekolah dasar yang ada di Kecamatan Cilongok, berdekatan dengan area objek wisata Germanggis, salah satu guru penjas Bapak Tamsi S.Pd, menyebutkan bahwa pembelajaran aktivitas luar kelas di ekolah tersebut masih di laksanakan di lapangan desa setempat saja, karena fasilitas sekolah yang belum memadai untuk melakukan pembelajaran aktivitas luar kelas, sehingga pembelajaran kurang maksimal. Berdasarkan hal diatas, penulis tertarik untuk melakukan kajian penelitian berjudul"Germanggis dan Potensinya Sebagai Prasarana Aktivitas Jasmani Siswa Sekolah Dasar".

\section{METODE}

Pada kajian ini termasuk dalam penelitian deskriptif kualitatif, sehingga data yang diperoleh berupa kata dan kalimat yang tertulis atau lisan dari orang atau perilaku yang diteliti. (Sugiyono, 2016) menjelaskan bahwa metode penelitian kualitatif merupakan penelitian yang dilakukan pada obyek alamiah, yang berkembang apa adanya, tidak mempengaruhi dinamika pada obyek tersebut, dalam penelitian kualitatif instrumennya adalah orang atau human instrument, yaitu peneliti sendiri. Dalam penelitian deskriptif peneliti juga dapat melakukan deskripsi yang mendalam dengan menggunakan aspek-aspek penelitian kualitatif.

Penelitian kualitatif merupakan suatu penelitian untuk memahami kejadian yang dialami atau terjadi oleh subjek peneliti secara mendalam dengan mendeskripsikan secara deskriptif dengan bentuk kata-kata dan bahasa (Moleong, 2017). Hal tersebut sejalan dengan apa yang ingin dicapai peneliti, yaitu ingin mengkaji dan memahami sikap, pandangan, perasaan, perilaku baik individu maupun kelompok yang tidak bisa diukur dengan angka saja. Untuk menafsirkan makna dari suatu peristiwa atau fenomena yang terjadi, penulis menggunakan metode penelitian kualitatif ini.

Lokasi penelitian ini bertempat di objek wisata Germanggis Kecamatan Cilongok, Kabupaten Banyumas. Informan dalam penelitian ini adalah pengelola objek wisata Germanggis, guru pendidikan jasmani, dan siswa sekolah dasar di Kecamatan Cilongok. Teknik penentuan informan dengan menggabungkan teknik snowball dan purposive sampling, dengan kriteria 1). Informan dianggap mengetahui informasi dan masalah secara mendalam, 2). Terlibat dalam proses pelaksanaan kegiatan, 3). Dapat dipercaya sebagai sumberdata, 4). Bersedia menjadi responden.

Data primer didapatkan dari hasil wawancara langsung kepada informan, sedangkan data sekunder merupakan sumber data yang tidak memberikan data secara langsung kepada pengumpul data. Instrumen penelitian menggunakan teknik observasi, wawancara, dokumentasi. Uji keabsahan data menggunakan teknik trianggulasi.

Triangulasi dapat didefinisikan sebagai salah satu teknik atau cara pengumpulan data dengan menggabungkan antara beberapa teknik pengumpulan data dan sumber data yang telah diambil (Sugiyono, 2016). Trianggulasi yang digunakan adalah trianggulasi teknik dan sumber. Trianggulasi teknik dilakukan peneliti dengan membandingkan data yang diperoleh dari hasil observasi di lapangan, wawancara kepada pengelola germanggis, guru pendidikan jasmani dan kepada siswa, serta hasil dokumentasi. 
Kemudian, triangulasi sumber dilakukan dengan membandingkan data wawancara dari informan.

Analisis data kualitatif dilakukan secara interaktif dan berlangsung secara menerus hingga tuntas dan datanya jenuh. Aktivitas dalam teknik analisis data yaitu pengumpulan data, reduksi data, penyajian data, dan penarikan kesimpulan (Sugiyono, 2016). Sedangkan analisis data yang digunakan adalah analisa interaktif model Miles dan Huberman, untuk teknik menganalisa datanya, ditunjukkan seperti gambar dibawah ini.

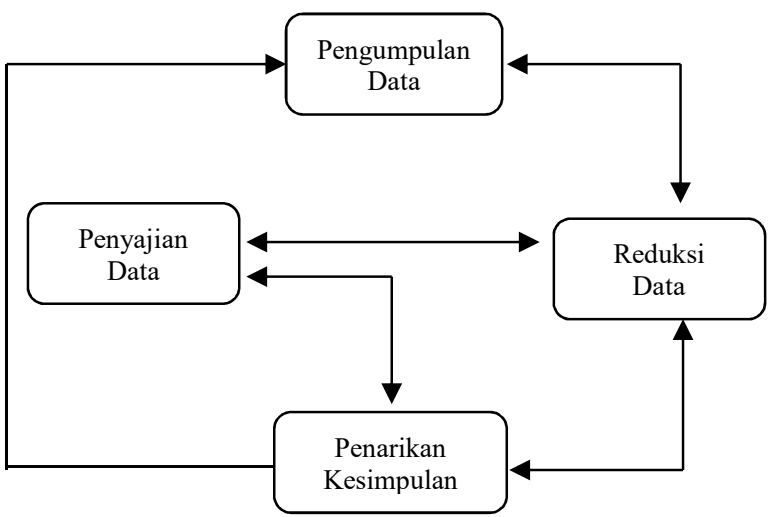

Gambar 1. Skema model analisis interaktif

(Sumber: Matthew B. Miles dan A. Michael

Huberman, dalam Demartoto, A (2008)

\section{Hasil Penelitian dan Pembahasan}

Pada penelitian ini diawali dengan tahapantahapan yaitu; observasi, wawancara, focus group discusion, dan dokumentasi (direkam melalui video). Wisata alam Germanggis ini dibuka awal tahun 2019 dan sampai saat ini ramai dikunjungi wisatawan terutama diakhir pekan. Germanggis terletak di kecamatan Cilongok, berjarak sekitar 21 kilo meter kearah barat dari kota Purwokerto. Arah ke obyek tersebut dapat masuk mulai dari desa Losari, Karangsari terus kearah karangtengah, lebaksiu terus naik kearah curug cipendok.

Deskripsi terkait kecamatan cilongok yang didalamnya terdapat wisata alam germanggis adalah; batas utara dengan kabupaten brebes dan tegal, batas timur dengan kecamatan karanglewas dan kedungbanteng, batas selatan dengan kecamatan ajibarang, purwojati, patikraja, batas barat kecamatan pekuncen, ajibarang. Lokasi Germanggis tepat dibawah sebelum sampai curug cipendok, kurang lebih berjarak 1,9 kilometer. Batas lokasi kecamatan cilongok tertera seperti pada tabel 1 berikut:

Tabel 1. Batas Kecamatan Cilongok

\begin{tabular}{c|c|c}
\hline No & Batas & Kecamatan/Kabupaten \\
\hline 1 & Utara & Kabupaten brebes dan tegal \\
\hline
\end{tabular}

\begin{tabular}{c|c|c}
\hline 2 & Timur & $\begin{array}{c}\text { Kecamatan karanglewas dan } \\
\text { kedungbanteng }\end{array}$ \\
\hline 3 & Selatan & $\begin{array}{c}\text { Kecamatan ajibarang, } \\
\text { purwojati, patikraja }\end{array}$ \\
\hline 4 & Barat & Pekuncen, ajibarang \\
\hline \multicolumn{2}{|c}{ Pengambilan data dilakukan dengan }
\end{tabular}
melibatkan pemilik dan pengelola objek wisata germanggis yaitu bapak Rubben Kurniawan dan bapak Aji. Bapak Ruben Kurniawan menjabat sebagai manager di Objek Wisata Germanggis berusia 24 tahun. Beliau merupakan alumni dari Politeknik ATMI Surakarta. Politeknik ini mencetak para lulusannya untuk siap kerja di sektor industri manufaktur. Selain itu beliau menjabat sebagai Kepala di Sekolah Menengah Kejuruan (SMK) Mulia Bakti Purwokerto. Sedangkan bapak Aji ditugaskan untuk membantu mengelola dan mengembangkan Objek wisata germanggis.

Bapak Aji merupakan anak dari kepala desa Karangtengah, sekaligus bekerja sebagai Guru di Sekolah Dasar Negeri 3 (SDN 3) Karangtengah Cilongok, informan pengelola ditunjukkan dalam tabel berikut:

Tabel 2. Informan Pengelola

\begin{tabular}{c|c|c|c}
\hline No & Nama & $\begin{array}{c}\text { Jabatan di } \\
\text { Germanggis }\end{array}$ & Pekerjaan \\
\hline 1 & Ruben & Manager & $\begin{array}{c}\text { Kep. } \\
\text { Sekolah }\end{array}$ \\
\hline 2 & Aji & Asisten Manager & Guru SDN \\
\hline
\end{tabular}

Untuk informan dari guru, telah dilakukan wawancara kepada beberapa narasumber yaitu: 1) Bapak Cahyo,S.Pd sebagai Guru Pendidikan Jasmani Olahraga dan Kesehatan (PJOK) di SDN 1 Pernasidi dengan masa jabatan mengajar selama 2 tahun, 2) Bapak Tamsi,S.Pd sebagai Guru PJOK di SDN 1 Karangtengah, telah mengajar selama 6 tahun, 3) Ibu Endang,S.Pd sebagai Guru PJOK di SDN 3 Karangtengah dengan masa jabatan mengajar selama 4 tahun, 4) Bapak Tirno,S.Pd sebagai Guru PJOK di SDN 3 Kalisari dengan masa jabatan mengajar selama 1 tahun, 5) Bapak Takum,S.Pd beliau sebagai Guru PJOK di SDN 1 Cilongok dengan masa jabatan mengajar selama 2 tahun. Informan guru pendidikan jasmani olahraga dan kesehatan, ditunjukan pada tabel 3 berikut:

Tabel 3. Informan Guru PJOK

\begin{tabular}{c|c|c|c}
\hline $\begin{array}{c}\mathrm{N} \\
\mathrm{o}\end{array}$ & Nama & $\begin{array}{c}\text { Pekerjaa } \\
\mathrm{n}\end{array}$ & Tempat kerja \\
\hline 1 & Cahyo,S.Pd & Guru & SDN 1 \\
PJOK & Pernasidi \\
\hline
\end{tabular}




\begin{tabular}{c|c|c|c}
\hline 2 & Tamsi,S.Pd & $\begin{array}{c}\text { Guru } \\
\text { PJOK }\end{array}$ & $\begin{array}{c}\text { SDN 1 } \\
\text { Karangtenga } \\
\text { h }\end{array}$ \\
\hline 3 & $\begin{array}{c}\text { Endang,S.P } \\
\text { d }\end{array}$ & $\begin{array}{c}\text { Guru } \\
\text { PJOK }\end{array}$ & $\begin{array}{c}\text { SDN 3 } \\
\text { Karangtenga } \\
\text { h }\end{array}$ \\
\hline 4 & Tirno,S.Pd & $\begin{array}{c}\text { Guru } \\
\text { PJOK }\end{array}$ & $\begin{array}{c}\text { SDN 3 } \\
\text { Kalisari }\end{array}$ \\
\hline 5 & Takum,S.Pd & $\begin{array}{c}\text { Guru } \\
\text { PJOK }\end{array}$ & $\begin{array}{c}\text { SDN 1 } \\
\text { Cilongok }\end{array}$ \\
\hline
\end{tabular}

Untuk informan dari siswa, juga telah dilakukan wawancara kepada beberapa siswa di beberapa sekolah dasar yaitu: 1) Rafli dan 2) Fikoh mereka berdua peserta didik kelas VI sekolah dasar di SDN 1 Karangtengah, 3) Afif dan 4) Reyhan, mereka berdua pada kelas VI sekolah dasar di SDN 1 Pernasidi, 5) Kinanti dan 6) Lala mereka berdua menduduki bangku kelas VI sekolah dasar di SDN 3 Karangtengah, 7) Raka dan 8) Putri dari SDN 1 Kalisari, 9) Satria Tunas Jati dan 10) Desnanta mereka berdua menduduki bangku kelas VI sekolah dasar di SDN 1 Cilongok. Informan dari siswa, ditunjukan pada tabel 4 berikut :

Tabel 4. Informan Siswa

\begin{tabular}{c|c|c|c}
\hline $\begin{array}{c}\text { N } \\
\text { o }\end{array}$ & Nama & $\begin{array}{c}\text { Kela } \\
\text { s }\end{array}$ & Asal Sekolah \\
\hline 1 & Rafli & VI & $\begin{array}{c}\text { SDN 1 } \\
\text { Karangtengah }\end{array}$ \\
\hline 2 & Fikoh & VI & $\begin{array}{c}\text { SDN 1 } \\
\text { Karangtengah }\end{array}$ \\
\hline 3 & Afif & VI & SDN 1 Pernasidi \\
\hline 4 & Reyhan & VI & SDN 1 Pernasidi \\
\hline 5 & Kinanti & VI & $\begin{array}{c}\text { SDN 3 } \\
\text { Karangtengah }\end{array}$ \\
\hline 6 & Lala & VI & $\begin{array}{c}\text { SDN 3 } \\
\text { Karangtengah }\end{array}$ \\
\hline 7 & Raka & VI & SDN 1 Kalisari \\
\hline 8 & Putri & VI & SDN 1 Kalisari \\
\hline 1 & Satria & VI & SDN 1 Cilongok \\
\hline 0 & Desnanta & VI & SDN 1 Cilongok \\
\hline
\end{tabular}

\section{Potensi Germanggis Untuk Dijadikan Prasarana Aktivitas Jasmani}

Germanggis terletak didataran tinggi, dikaki gunung Slamet bagian barat daya. Pada lokasi ini kita dapat melihat kota ajibarang dan cilongok dari ketinggian. Pada awalnya lokasi yang kini didirikan sebagai tempat wisata, dahulu sebelumya ditanami dengan kebun buah manggis.
Lokasinya yang ada dilereng kaki Gunung Slamet ini, topografinya berbukit. Dengan kondisi alam seperti demikian, mengilhami penamaan tempat wisata, yaitu berasal dari kata "Ger" yang berarti Bukit dan "Manggis" berarti buah manggis. Tempat wisata Germanggis merupakan kawasan wisata alam berkonsep wisata fun education. Pengunjung bisa menikmati alam bebas yang sekaligus bisa mengadakan camping. Potensi dari Germanggis yaitu memiliki sumber alam yang sangat bagus dengan mata air yang cukup banyak, lokasi wisatanya berdiri diatas lahan seluas 5 hektar, dengan area yang sudah terpakai 1,5 hektar, dan masih ada sekitar 3,5 hektar lagi, untuk bisa dikembangkan (seperti ditunjukkan pada gambar 1)

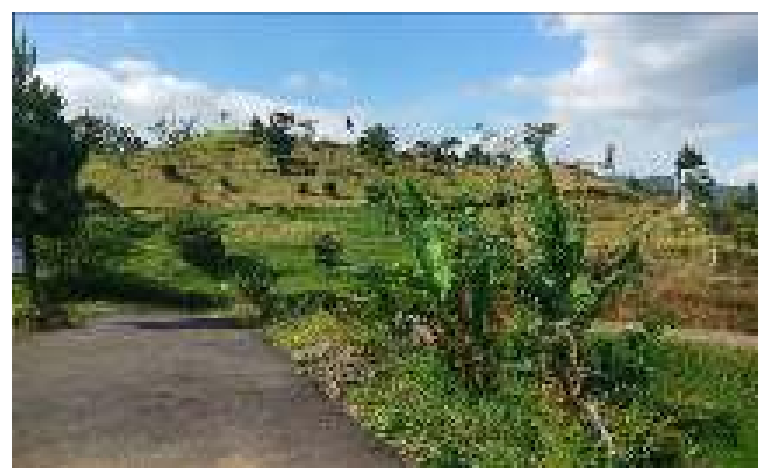

Gambar 1. Lahan yang masih luas

Selain itu udaranya masih terasa sangat sejuk, minim polusi udara, pandangan alamnya baik saat sunrise dan sunset pada cuaca terang sangat indah. Dengan kondisi seperti ini, lokasi wisata germanggis memiliki potensi yang bagus untuk dijadikan tempat prasarana aktivitas jasmani baik bagi siswa, guru maupun masyarakat umum (pemandangan alam sekitar yang indah ditunjukkan pada gambar 2)

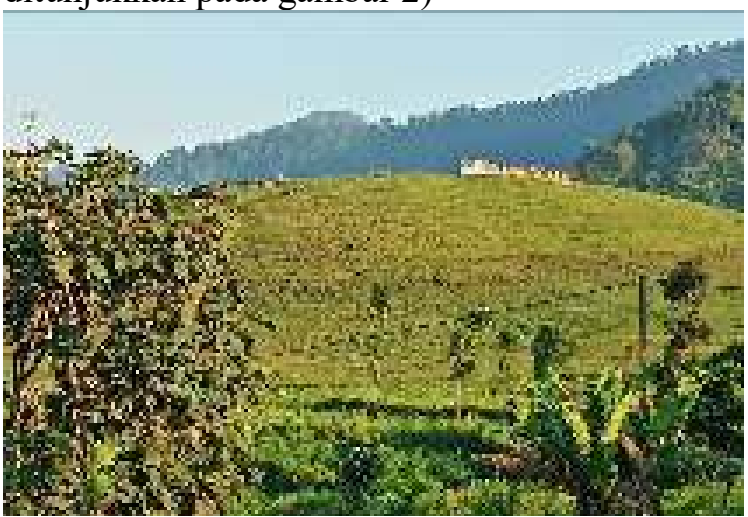

Gambar 2. Pemandangan alam sekitar yang indah 


\section{Faktor Penghambat Dalam Pengembangan Germanggis Sebagai Prasarana Aktivitas Jasmani}

Dalam pengelolaan tempat wisata ini terdapat beberapa faktor yang sementara menjadi penghambat, hal ini diantaranya dapat dianalisa sebagai berikut: 1) Lokasi tempat tersebut cukup jauh dari jalur kendaraan umum, sehingga bagi para pengunjung harus naik kendaraan pribadi baik motor, mobil MPV/ SUV, ataupun menyewa kendaraan bila berombongan seperti bus kecil, mobil ELF, sementara bus kapasitas besar (50 orang) belum bisa naik masuk kelokasi, 2) Walaupun jalannya beraspal hotmix, tetapi jalan menuju lokasi menanjak, jalannya naik dibeberapa titik dengan kemiringannya hampir 50 derajat, maka bagi pengunjung yang akan kelokasi, harus senantiasa mengecek kondisi kendaraan, dan memastikan dalam kondisi yang prima (seperti pada gambar 3 dibawah ini)

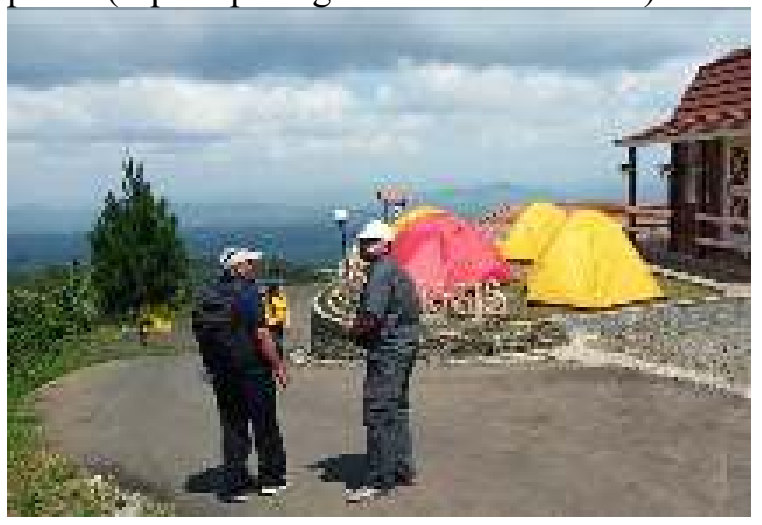

Gambar 3. Jalan menuju lokasi

Hasil penelitian ini sedikit berbeda dengan penelitian lain yang serupa mengenai pengembangan wisata bahari mande menyebutkan bahwa permasalahan mendasar pada masyarakat di sekitar kawasan wisata Bahari Mande adalah sebagai berikut 1) Ketersediaan dana, dan kualitas sarana prasarana parwisata olahraga yang masih terbatas, 2) Promosi dan pemasaran pariwisata olahraga Mande yang belum maksimal, 3) Persepsi negatif dari sebagian masyarakat Mandeh tentang pariwisata olahraga, masayarakt berfikir kalau konsep wistaa olahraga selalu identik dengan pakaiaan yang membuka aurat (Komaini, 2018).

\section{Faktor Pendukung Dalam Pengembangan Germanggis Sebagai Prasarana Aktivitas Jasmani}

Selain adanya faktor penghambat, dalam pengelolaan tempat wisata ini terdapat juga faktor pendukungnya, hal ini diantaranya dapat dianalisa sebagai berikut: 1) Dukungan dari masyarakat dan pemerintah desa setempat, hal ini ditunjukkan dengan melibatkan sebagai penjaga parkir dan penjaga tiket serta warung makan (pelibatan warga sekitar dalam ikut mendukung usaha wisata, ditunjukkan seperti gambar 4, dibawah ini)

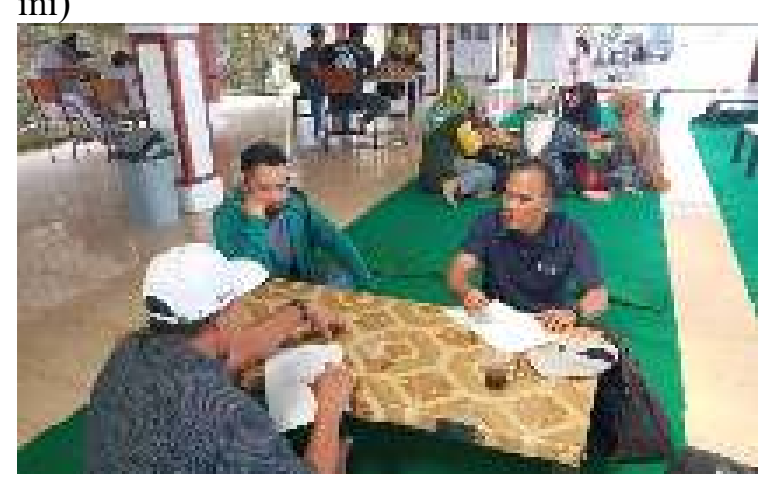

Gambar 4. Pelibatan warga sekitar

2) Harga Tiket Masuk (HTM); harga tiket masuk ke lokasi ini sangat terjangkau yaitu Rp 5.000,-per orang di hari kerja (weekdays), Rp 10.000,- per orang di hari sabtu dan minggu (weekend) atau di hari libur nasional, serta Rp.15.000,- per orang di malam tahun baru: 3) Tersedianya lahan parkir yang cukup luas (seperti ditunjukkan pada gambar 5)

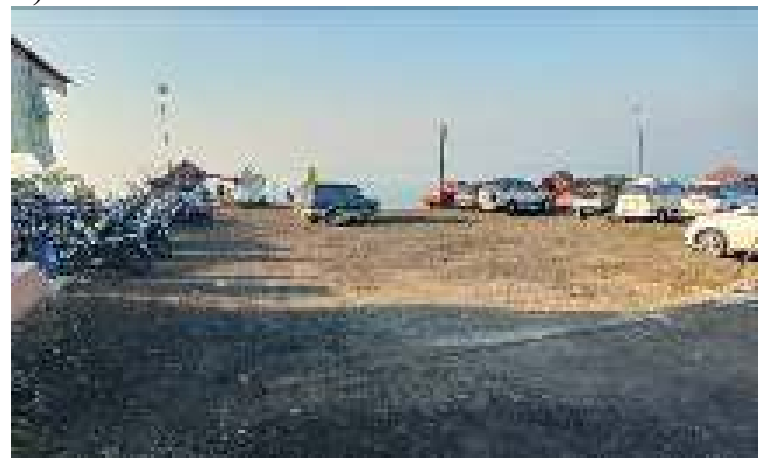

Gambar 5. Area Parkir Luas

4) Tersedianya area camping dengan fasilitas musholla, ada di dua tempat yang strategis, hal ini memudahkan pengunjung untuk beribadah diselasela kegiatan, 5) Tersedianya stan warung makan yang menyediakan masakan khas banyumas, jam operasional dibuka mulai pukul 08.00 sampai pukul 18.00 dari hari senin sampai hari jumat dan sampai pukul 21.00 di hari sabtu dan minggu. Kantin yang disediakan terdapat di dua lokasi berbeda, disisi atas dekat area puncak camping, dan disisi bawah kantinnya dekat dengan pendopo. Kedua kantin dilengkapi juga dengan fasilitas toilet dan mushola, (seperti ditunjukkan pada gambar 6 dibawah ini): 


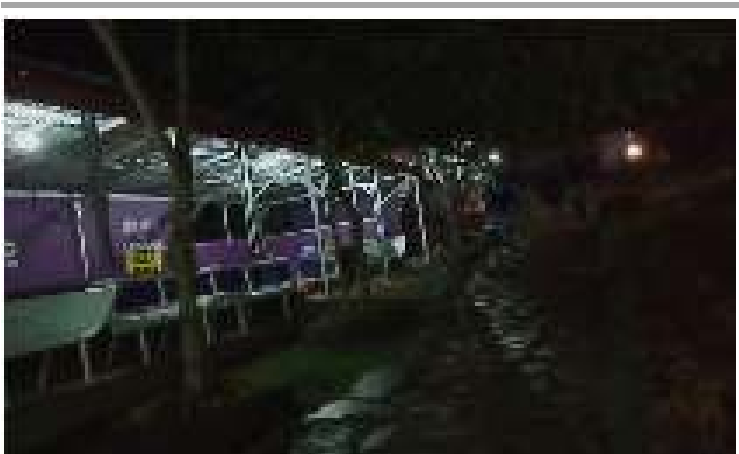

Gambar 6. Fasilitas Kantin

6) Banyak terdapat spot foto yang menarik, hal ini menjadi daya tarik tersendiri bagi para pengunjung, karena spotnya bervariasi (seperti ditunjukkan pada gambar 7 .

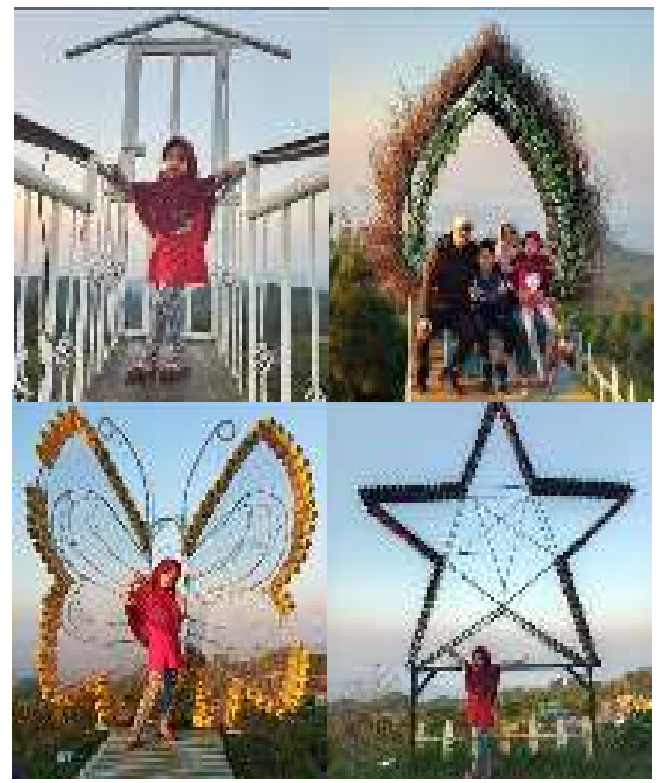

Gambar 7. Lokasi Spot Foto

Terdapat area camping yang mampu menampung 100 tenda, apabila pengunjung ingin menginap telah disediakan tenda dome, yang bisa digunakan untuk 3 orang dewasa cukup dengan tarif sewa regular ( Rp 50.000,- ini termasuk tenda, matras tanpa softdrink) selain itu disediakan juga persewaan tenda dengan Paket 1: (Rp 100.000,: untuk 4 orang, ini termasuk tenda, matras, soft drink), Paket 2: (Rp 150.000,-: untuk 4 orang, ini termasuk tenda, matras, kasur, soft drink) biasanya para pengguna, pesan tempat terlebih dahulu untuk mendapatkan area camping yang diinginkan atau juga bisa on the spot, 8) Adanya arena bermain untuk anak seperti ayunan dan juga tempat bermain dilengkapi dengan karpet rumput. Selain itu ada area outbond yang masih dalam dengan memanfaatkan bentangan alam yang berbukit. Sedangkan untuk area camping terdiri ada tiga tingkat. Area untuk camping seperti ditunjukkan pada gambar 8

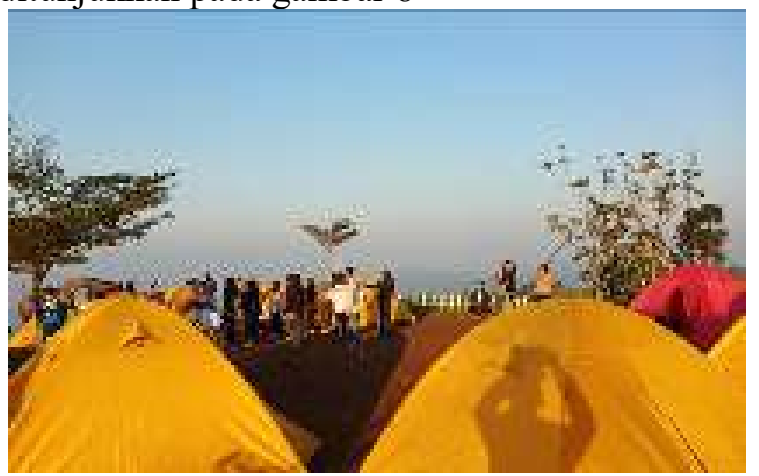

Gambar 8. Area Camping Dengan Fasilitas Tenda

Tersedianya resort sebanyak 10 unit, dengan ukuran rata-rata ( 4 × 6 meter), resort ini dilengkapi fasilitas seperti; karpet lantai untuk duduk bersantai, kursi dan meja kecil, dispenser untuk air minum, kamar mandi. Untuk harga sewa rumah penginapan di Germanggis Resort sekitar Rp. 500.000,- per malam. Hal ini memudahkan pengunjung yang ingin bermalam tanpa khawatir kehujanan (ditunjukkan pada gambar 9)

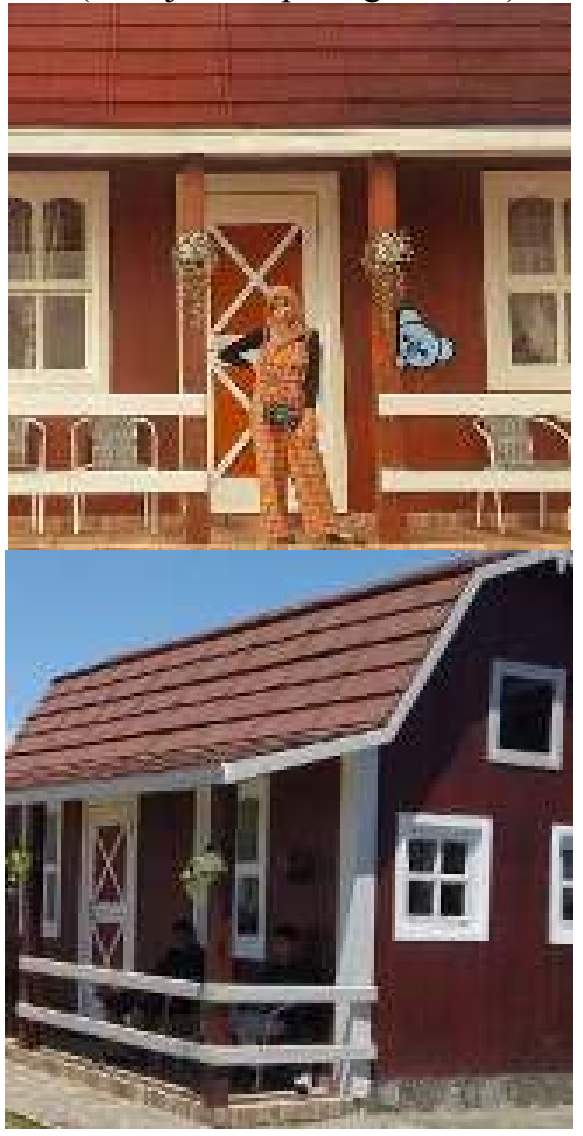

Gambar 9. Fasilitas Resort 


\section{KESIMPULAN}

Dari hasil penelitin dapat disimpulkan bahwa respon pengelola wisata sangat baik untuk terus berupaya mengembangkan potensi yang ada, sehingga dapat menarik jumlah wisatawan tidak hanya dari masyarakat umum tapi juga dari kalangan sekolah, guru dan siswa. Setelah melakukan pembelajaran aktivitas jasmani berbasis outdoor activity, guru dan siswa merespon dengan baik untuk prasarana di germanggis ini, sehingga potensi yang dimiliki, dapat digunakan dan dikembangkan sebagai prasarana pembelajaran aktivitas jasmani berbasis outdoor activity bagi siswa sekolah dasar.

\section{DAFTAR PUSTAKA}

Castyana, B. (2013). Pengaruh Program Pariwisata Olahraga Borobudur Interhash 2012 Dalam Meningkatkan Kunjungan Wisatawan Ke Daerah Tujuan Wisata Kabupaten Magelang. JSSF (Journal of Sport Science and Fitness), 2(1).

Feldman, A. F., \& Matjasko, J. L. (2005). The role of school-based extracurricular activities in adolescent development: A comprehensive review and future directions. Review of Educational Research, 75(2), 159-210. https://doi.org/10.3102/0034654307500215 9

Festiawan, R. (2020). Application of Traditional Games: How Does It Affect the Children's Fundamental Motor Skills? Menssana, 5(2), 157-164.

Festiawan, R., \& Arovah, N. I. (2020). Pengembangan "Buku Saku Pintar Gizi " Untuk Siswa: Alternatif Media Pembelajaran untuk Meningkatkan Pengetahuan Gizi Olahraga. Physical Activity Journal, 2(1), 188-201. https://doi.org/https://doi.org/10.32424/1.pa ju.2020.1.2.2436 Abstrak

Festiawan, R., Ngadiman, N., Kusuma, I. J., Nurcahyo, P. J., \& Kusnandar, K. (2019). Pengembangan Model Pembelajaran Pendidikan Jasmani Berbasis Games, Education, and Visualisation (GEV) Untuk Meningkatkan Pengetahuan Kesehatan Reproduksi Remaja. Jendela Olahraga, 4(2), 13-25. https://doi.org/10.26877/jo.v4i2.3678
Festiawan, R., Raharja, A. T., Jusuf, J. B. K., \& Mahardika, N. A. (2020). The Effect of Oregon Circuit Training and Fartlek Training on the VO2Max Level of Soedirman Expedition VII Athletes. Jurnal Pendidikan Jasmani Dan Olahraga, 5(1), 62-69.

https://doi.org/10.17509/jpjo.v5i1.23183

James, J. K., \& Williams, T. (2017). SchoolBased Experiential Outdoor Education: A Neglected Necessity. Journal of Experiential Education, 40(1), 56-71. https://doi.org/10.1177/1053825916676190

Kamaludin, Ngadiman, Festiawan, R., Kusuma, I. J., \& Febriani, A. R. (2020). Pengembangan Permainan Pecah Piring Sintren : Pemanfaatan Olahraga Tradisional Pada Pembelajaran untuk Meningkatkan Kemampuan Motorik Kasar Anak. TEGAR: Journal of Teaching Physical Education in Elementary SchoolJournal of Teaching Physical Education in Elementary School, 3(5), 37-45.

Karisma, F. (2012). Manajemen Pengembangan Pariwisata Kabupaten Semarang di Dinas. Universitas Diponegoro.

Komaini, A. (2018). Pengembangan Pariwisata Olahraga (Sport Tourism) Di Kawasan Wisata Bahari Mande. Sporta Saintika, 2(2), 272-279.

Kusuma, I. J., Nurcahyo, P. J., Wahono, B. S., \& Festiawan, R. (2020). Pola Pengembangan Wisata Olahraga Rumpit Bike And Adventure Di Kabupaten Banjarnegara. Menssana, 5(1), 46-52. https://doi.org/10.24036/jm.v\%vi\%i.133

Moleong, L. J. (2017). Metodologi Penelitian Kualitatif (Edisi Revisi). In PT. Remaja Rosda Karya.

Nguyen, N. (2015). Incorporating Outdoor Education into the Physical Education Curriculum. Strategies: A Journal for Physical and Sport Educators, 28(1), 37-41. https://doi.org/10.1080/08924562.2015.981 126

Nurcahyo, P. J., Festiawan, R., Budi, D. R., Listiandi, A. D., Ngadiman, N., \& Syafei, 
M. (2020). Rules and Routines in Covid-19: How Are The Applications In Physical Education Learning In School? Jurnal Menssana, 5(2), 130-138.

Putra Thama, A., \& Dharmawan, N. K. S. (2019). Penyelenggaraan Pariwisata Olahraga: Perspektif Rekomendasi Pemerintah Daerah. Acta Comitas, 4(2), 213. https://doi.org/10.24843/ac.2019.v04.i02.p0 5

Rahayu, E. D., \& Firmansyah, G. (2019). Pengembangan Permainan Tradisional Lompat Tali Untuk Meningkatkan Kinestetic Intelegency Pada Anak Usia 1112 Tahun. Jendela Olahraga, 4(2), 8. https://doi.org/10.26877/jo.v4i2.3611

Richards, K. A. R., Jacobs, J. M., Wahl-alexander, Z., Richards, K. A. R., Jacobs, J. M., \& Wahl-alexander, Z. (2018). Preservice physical education teacher socialization through an outdoor education field experience. Journal of Adventure Education and Outdoor Learning, 00(00), 1-15. https://doi.org/10.1080/14729679.2018.148 3252

Sugiyono. (2016). Metodologi Penelitian Kuantitatif, Kualitatif, dan R\&D. In $C V$ Alfabeta.

https://doi.org/https://doi.org/10.3929/ethzb-000238666

Wicaksono, P. N., Kusuma, I. J., Festiawan, R., \& Widanita, N. (2020). Evaluasi penerapan pendekatan saintifik pada pembelajaran pendidikan jasmani materi teknik dasar passing sepak bola Evaluation of application of scientific approach in physical education learning basic technical material for football passing. Jurnal Pendidikan Jasmani Indonesia, $\quad 16(1), \quad 41-54$. https://doi.org/https://doi.org/10.21831/jpji. v16i1.29774

Widodo, R. W. (2016). Analisis potensi pariwisata olahraga di kabupaten wonosobo. 1(1), 1-71. 